\title{
Using My 'You Lie Moment' to Theorize Persistent Resistance to Critical Multicultural Education
}

\author{
Patricia L. Marshall \\ North Carolina State University \\ U.S.A.
}

ABSTRACT: In this article I detail correspondences between a breach of decorum that occurred during a speech delivered by President Obama before a joint session of the United States Congress and an encounter between a teacher education student and me in a graduate-level multicultural education course. The encounter served as a powerful, albeit inadvertent, impetus to theorize the nature of persistent resistance to diversity and critical multicultural education in one teacher education unit.

\section{KEYWORDS: critical multicultural education, persistent resistance, teacher} education, multicultural education course, President Obama

A Breach of Decorum on the National Stage

A 'Moment' in a Teacher Education Course The First Three Weeks

A Public Dissing

R-E-S-P-E-C-T: Too Much to Expect?

A Moment of Grievance

My Connection with the President

Lessons Learned in a Moment

The Plasticity of Persistent Resistance

Notes

References

Author Contact

The concept of multicultural education was introduced to U.S. teacher education discourse over four decades ago and it has faced opposition and resistance ever since. As a teacher educator I have found that resistance to my work vis-à-vis critical multicultural education has manifested in many forms. However, my most recent experience was atypical. It reverberated in a way that prompted me to theorize insidious and complex layering of resistance in the context of one teacher education department. I now refer to that experience as my "you lie moment." In the tradition of autoethnographic analysis (Boylorn \& Orbe 2014; Ellis \& Bochner, 2000; Kaplan, 1993) I reflect in this article on aspects of my "moment," including how it prompted me to consider anew the struggle that has defined my work as a teacher educator dedicated to social justice for more than 25 years and how it allowed me to gain more nuanced insight into the truly plastic capability of resistance to critical multicultural 
education.

\section{A Breach of Decorum on the National Stage}

Less than eight months into his first term, President Barack Obama stood behind a lectern in the U.S. House of Representatives to deliver a speech that would be broadcast live across the nation. His purpose was to detail to lawmakers and the American public his plan for national health care reform as laid out in the then proposed Patient Protection and Affordable Care Act (PPACA). Political analysts would later debate its overall substance, but well before his speech was concluded, the impact was unexpectedly blunted. The most memorable words from that evening did not come from the President at all. Instead, like a shot in the dark, a two-word phrase ("You lie!") was hurled at the President from the legislative chamber. Cameras panned and rumblings spread throughout the auditorium while the invective hung in the air as seconds passed. Media commentators struggled for explanation since few knew who had been responsible for the brazen breach of congressional decorum. All were aware, however, that the President of the United States had been stunned into momentary silence. As if righting himself from a sudden blow to the gut, the President uttered a nearly inaudible reply ("It's not true") to his faceless accuser. Order soon resumed, and President Obama proceeded to deliver the remainder of his speech. The public soon learned that the verbal assault upon the President had come from U.S. Representative Joe Wilson. Analysts across the political spectrum criticized Wilson for the unprecedented outburst, and prominent lawmakers from the two major political parties unanimously condemned his act. Within days Wilson contacted the White House, and shortly thereafter media clips showed President Obama graciously accepting his apology.

The decision by Wilson, a White Republican from South Carolina to shout "you lie" at the President represented far more than a simple breach of decorum. Rather, this boorish public act symbolized a collective disrespect and loathing for the President himself, the first Black person elected to the office. Strident political partisanship buttressed by thinly veiled race bating was the backdrop to Wilson's outburst. Analysts noted that its coarseness was emblematic of the depth of opposition to President Obama held by many of the lawmakers and officials in attendance that evening, as well as citizens throughout the nation (Hahn, 2012; Toobin, 2012). According to Hahn (2012), the unabated resistance President Obama experienced throughout his first term (and into his second) has important historical antecedents. It is traceable to the backlash that members of the dominant White population have always visited upon Blacks who attempted to exercise real or symbolic power over Whites (p. 6).

Like millions of others, I watched on television with great anticipation the night President Obama delivered that speech. I was optimistic about the changes that might be forthcoming during his presidency even though I felt at that early stage he was receiving an especially negative reception from his fellow 
politicians. Thus, I felt revulsion as I observed the "you lie" moment unfold. Little did I know that I would later be party to an incident in one of my graduate courses that, for me, would parallel what I had seen happen to the President of the United States.

\section{A "Moment" In a Teacher Education Course}

The incident occurred in a graduate-level introductory multicultural education course. Most of the students were pursuing master's degrees, although some were doctoral students. Many were currently working as classroom teachers and nearly all had previous professional experience in K-12 public school settings. The course was organized around four dimensions of multicultural teaching concerns (Marshall, 1996; Marshall, 2002a) with a major aim of promoting introspection and critical reflection on the complexities of being a professional educator in contemporary U.S. public schools. This broad aim was buttressed by an exploration of the intersections between and among different forms of oppression (Collins, 2009; Hartman, 2003), with particular attention given to manners in which the ethnoracial and economic class positions of K-12 children and youth are often entangled in complex schooling protocols that promote the disadvantage of some groups, unfair advantage of others, and the mis-education of virtually all (Nieto, 1999; Noguera, 2001; Orfield \& Lee, 2006). Additionally, students in my course were introduced to diverse orientations to multicultural education (Jenks, Lee, \& Kanpol, 2001) as well as diverse multicultural teaching approaches (Sleeter \& Grant, 2009). The 16-week, threecredit-hour course met one night per week with a 10-minute break incorporated about halfway through each class session. I characterize my teaching as interactive even though most sessions include a small amount of lecture. To illustrate concepts and add variety, I use a number of videos, small and large group activities, simulations, and discussions.

\section{The First Three Weeks}

I began the course by sharing information about the demographic character of the K-12 schools in our state, which has been changing for a number of years. Most of the students in the course were aware of some features of the demographic change (e.g., increases in the Hispanic student population); however, none was aware of the degree of dissimilarity between the ethnoracial character of the state's K-12 student population and its K-12 teacher population. In short, the students seemed genuinely surprised to learn that our state is very much in alignment with what Sleeter (2001) termed the "overwhelming whiteness" in the teaching force, which Zumwalt and Craig (2008) confirmed in their discussion of who is teaching in the nation's schools. Over the next two class sessions, I assigned the students to read a number of articles about 
multicultural education including Banks' (2004) comprehensive treatment of its historical development and dimensions. Through one of my short lectures, I provided a general overview of theoretical frameworks that would be used throughout the course. Critical race theory was one of the frameworks introduced, and I assigned the students to read Ladson-Billings' (1998) article that outlines its major concepts and implications for education. Also, I briefly introduced diverse teaching approaches that would be explored in depth later in the semester and showed the video Culturally Responsive Teaching (Chinn, 2004). This all served as the backdrop for a short interactive activity designed to help my students to start looking at, and thinking about, U.S. schools through a more critical lens.

The activity was from the book 52 Activities for Exploring Values Differences (Stringer \& Cassiday, 2003). Its purpose is to promote thinking about the basic diversity among people's values and to help students recognize that the values they may take for granted (and defend) are rarely universal. I used this activity as a precursor to engaging my students in explorations of how schooling conventions, classroom activities, curriculum content, and so on reflect particular value orientations that too often are grossly out of synch with the worldviews of children and youth from some backgrounds, while at the same time they are well in alignment with the worldviews of others. The activity consists of a list of statements (e.g., eating at certain times, calling a waiter with a hissing sound, being calm and controlled at all times) each of which students were instructed to label as an example of either a personal value (unique to an individual), a cultural value (shared by a group whose members have a common history and/or contemporary socioeconomic circumstance), or a global value (shared by all people irrespective of ethnoracial, cultural, historical backgrounds). I assigned students to complete the activity independently at first, and then they were to form small clusters of four to five members each. In the clusters students were to briefly discuss their personal categorization of each item and then identify the one or two items for which there had been the most agreement in classification among the cluster. Also, they were to identify the one or two items for which there had been the greatest dissimilarity in classification and to speculate about reasons for the differences. Depending on the verbosity of the class as a whole, and based on past experience, typically this activity takes 35-45 minutes and therefore can be completed in the context of one class session. I had introduced the activity near the end of the third week's class session and felt pleased that the students were anticipating returning to it the following week. It was when the class met the fourth week that my "you lie moment" occurred.

\section{A Public Dissing}

I opened the class session by immediately assigning the students to reconvene their small clusters from the previous week. My plan was to allot no more than 10 minutes for them to revisit their ideas, and then I was going to 
facilitate a large group discussion about the implications of the short activity for classroom/school interactions. The minutes lapsed and I announced it was time to convene as a large group. A few students immediately began re-positioning their seats for the large group discussion. In the meantime, I circulated among the clusters greeting each student individually to demonstrate lightheartedly that I had now learned the names of everyone in the course. A couple of students said "congratulations" to me as I recited each successive name correctly. The atmosphere was light and somewhat playful as it had been during the previous three weeks. I arrived at the final cluster and saw that those students had not yet begun to join the large group. By now the noise level in the room had risen with virtually all of the students from the other clusters chatting and repositioning their seats in anticipation of the large group discussion. Rather than continue with reciting names, I simply reminded the last cluster that the large group discussion was about to begin. To my surprise, a White female student in that last cluster, Camille $^{1}$, responded to me in an unusually forceful tone. She indicated her group had not had sufficient time to complete the activity. I paused and then replied to Camille that I felt she had spoken disrespectfully to me. I added lightly that I was calling her attention to her tone because this was the second time she had spoken to me in this manner. ${ }^{2}$ Camille did not deny my claim. Instead, she repeated that her group had not had sufficient time to complete the activity. At that point I reminded her that the activity had begun last week, that the time I allotted this week was for each small cluster to simply recap its discussion from the previous week, and that the more significant part of this activity would occur in the large group discussion. By now the cluster of students with whom she had been working were re-positioning their seats to join the large group discussion. Camille did not re-position her seat; rather, she retreated to a different seat nearer the rear of the classroom. I began to facilitate the whole class discussion with the intention for all the students (on their own initiative or through my invitation) to be actively engaged as had been the case during the previous weeks. The discussion was progressing well when I noticed that Camille was wiping her eyes and sniffling. I panned the class and saw another White female student, who was seated several feet away, look in Camille's direction. It was clear now that Camille was crying and her sniffling had attracted attention.

I did not respond as soon as I recognized Camille's apparent distress, but I did make a conscious decision not to ignore her outright. Having seen the one student respond to the sniffling, I assumed others as well were aware that Camille was in a state of upset. I walked over to where Camille was seated, and in a low voice I invited her to excuse herself from the classroom to regain her composure. Maintaining a gaze at her computer screen, with one hand Camille manipulated her keyboard and with a tissue in the other she wiped at her nose. She did not respond to my request, nor did she motion to leave the classroom, yet her sniffling was now more audible. I then said to Camille that I could see she was upset about something, but that she was now disturbing the rest of the class. I asked that she excuse herself. Camille angrily shouted that she was not going anywhere. She announced that she was "30 years old" and, in an apparent response to my saying that I could see she was upset, Camille said, "You don't 
know me." Her response reflected a public degree of upset that made it difficult for me to simply resume the large group discussion as if nothing had happened. Thus, to no one in particular, I asked a somewhat resigned question, "what to do?" ${ }^{3}$ For a few seconds there was absolute silence. Then Camille broke the silence by saying, “They won't say anything because they're all afraid of you. This is supposed to be a class about cultural responsiveness; yeah, some cultural responsiveness." She then punctuated her harangue with, "I don't know why you are picking on me." I was absolutely stunned and simply looked out at the group of students who, in turn, looked back at me as if waiting for my retort. I said nothing. Eventually, a third White female student who was sitting not far from me but some distance away from Camille said she had not heard Camille's crying, and then, almost apologetically, she suggested we continue the discussion. The other students in the class remained silent. I paused a few seconds and then restarted the discussion. The tension was palpable. A few students shared their ideas, but the momentum of the discussion about the values activity had been lost. I brought that opening segment of the evening's session to a close by sharing the broad ideas that were intended to come from the activity. Transitioning to the main focus for that class session, I began a brief lecture in which I provided a synopsis of the assigned readings for the evening. About 15 minutes passed and then it was time for the break. The students filed out of the classroom as usual to make their way to restrooms and snack machines. Camille remained seated and, uncharacteristic for me, I retreated to my office on the next floor in the building for a much needed 10-minute break.

When I returned to the classroom, Camille was still seated in the position she had staked out prior to the break, and she was still focused on her computer screen. She continued to sniffle but now far less audibly. For the second half of the session I had planned for the students to work in small groups to discuss questions and complete activities related to the readings for that class session. I called the names of the students I had pre-assigned to each group ${ }^{4}$, and distributed particular questions and a task for each group to complete. Once all groups had been formed, I asked each to congregate in a different section of the classroom to engage in a 25-minute work session. This would be followed by a report-out from each group to the class as a whole. Students moved to the different areas of the room to begin working on their assigned tasks, and the lightness that had characterized the atmosphere of the course during the previous three weeks seemed to return. Camille did not move. I had called her name (as I had every other student's) signaling to which group she had been preassigned, but I was careful not to initiate another verbal exchange with her directly. Once all the groups were organized and working on their respective tasks, I watched as an exceedingly brief but somewhat disconcerting verbal exchange occurred between Camille and another student. LaDonna, the lone Black student in class that particular evening, noticed that her group was short one member. Calling out to the missing member she said, "Camille honey, are you going to join us?" Camille answered "yes" after which she closed her computer, collected her belongings, and walked over to the other side of the classroom to join the waiting group members. 


\section{R-E-S-P-E-C-T: Too Much to Expect?}

That evening after class my mind raced to the point that upon going to bed I could not sleep. I sent an email to the Department Head explaining what had happened and requesting that Camille be advised to drop the course ${ }^{5}$. In the days immediately following the "moment," I found myself attempting to suppress my personal feelings and amplify my professional self by focusing on how I would start class the next week. I contemplated whether to proceed with the scheduled topic or to engage the students in a discussion about what had occurred between Camille and me by identifying connections to the content of the course-perhaps focusing on the possibility that value differences had been the source of the tension between us. Surely, I reasoned, the incident had introduced a useful, if awkward, teachable moment. But despite my efforts to recast the "moment," I felt revulsion at the blatant disrespect Camille had shown me. Curiously, a thought that gnawed at me was how I had been perceived by my other students. After all, Camille had publicly accused me of "picking on" her and she had claimed the students were "all afraid" of me. What could I possibly have done (so early in the semester, no less) to make the entire class fear me?

I reflected on how odd it seemed when I realized Camille was sobbing. I certainly had not raised my voice to her, nor had I issued an insult. Indeed, the opposite had been the case. Camille stood about two to three inches taller than I, and she appeared to outweigh me by at least 15 pounds. So why was Camille crying? When I juxtaposed the tears with her full-throated outburst, the two struck me as wholly incongruous. I had been irrefutably dissed and reduced to silence, yet I was now wondering whether my other students had perceived me as the aggressor. I knew my expectation to be accorded respect from students was solid. Still the irony was not lost on me that I was now troubled by an intrusive thought that my efforts to fully enact my legitimate position as professor had been supplanted by one of the basest stereotypes of Black women as domineering, threatening, and angry (Collins, 2009; Donovan, 2011; Tillman, 2011). As the time for the fifth class session drew nearer, I realized that to revisit the contours of the "moment" with the class obviously was not the way to go. I could not have done it anyway because I had already arranged for the entire class to attend a special presentation on campus about religion in public schools with a focus on Islam. In the immediate aftermath of the "moment," I had temporarily forgotten about that presentation.

The following week, with the notable exception of Camille, all of the students from my course were in attendance at the presentation about Islam as well as tens of students from other courses. It lasted just over three hours with a break midway through for light refreshments. During the break a student made a beeline to where I was seated in the auditorium, greeted me, and then asked how I was doing. Judging from the student's facial expression, I sensed something unusual about this otherwise ordinary query, so I asked, "What do you mean?" In a hushed tone, the student said, "You know, the situation that 
happened in class last week. I was just wondering how you were doing after that?" The student was LaDonna, the lone Black woman who, the night of the "moment," had invited Camille to join the second small group activity. It was obvious LaDonna was concerned about me, but I evaded the direct focus of her question and instead spoke of my general well-being. LaDonna's facial expression now suggested that I had thwarted additional comments she wanted to share about what had happened between Camille and me. ${ }^{6}$ When the class met in its usual location the next week, I proceeded with the planned activities as if the "moment" had never occurred. Camille, on the other hand, had decided quite differently.

\section{A Moment of Grievance}

About three weeks before the semester concluded, the head of my academic department requested to have a meeting with me wherein I learned Camille had met jointly with the Assistant Dean for Student Engagement (ADSE) and the Department Head to discuss filing a formal grievance against me. Several weeks had lapsed since their meeting, but I was told that I was being contacted at this point to make me "aware" of the situation. According to the Department Head, it seemed unlikely Camille would be pursuing the grievance beyond that initial meeting. Nonetheless, I was incredulous and so I questioned what possible grounds she could use to justify a grievance against me. Moreover, I speculated about Camille's mental state as I now coupled her efforts to file a grievance against me with the "you don't know me" statement she had made the night of the "moment." At the suggestion of the Department Head, I met with the ADSE to learn about the specifics of the university's grievance policy, including what I would need to do to defend myself against charges should Camille elect to move forward with her complaint.

Through the ADSE's broad description of the complaint ${ }^{7}$, I learned Camille had detailed the "moment" (i.e., what was said and by whom) nearly identically to the way that I had. I asked what Camille's response had been to learning that her account of the "moment" was largely in alignment with mine. The ADSE responded that Camille perceived I had been "unprofessional" and had subjected her to a "horrifying and humiliating experience." Apparently, Camille had been quite emotional as it was also noted that in the meeting she wept almost uncontrollably. I reasoned aloud that if this were to be the extent of Camille's "complaint" then surely it would not hold up as a legitimate justification to file a grievance against me. The ADSE responded that the university policy defines grievance worthy complaints as those that fall into at least one of three categories: discrimination, harassment, and/or retaliation. As the complainant, Camille would be required to provide credible evidence to corroborate allegations against me. According to the ADSE, Camille was asked whether I had discriminated, harassed, and/or retaliated against her, to which Camille conceded that I had not committed any of those offenses. I also learned that as 
an alternative to filing a formal grievance, Camille was offered the option of mediation wherein she and I would jointly attend a session facilitated by the ADSE with the goal of "resolving" our conflict. Although I was unsure what the resolution might entail, I was amenable to this idea. For her part, I learned Camille had refused to attend any meeting in which I would be present. I also learned she was calling for me to be reprimanded by upper administration in order "to protect" other students from me. Having been informed that her complaint against me was not grievance worthy, I assumed Camille also recognized that I would not be facing censure from the university based on her request and apparent allegation that I was a threat to other teacher education students. Thus, in the days immediately following my meeting with the ADSE, I was uneasy on campus because I now realized that I really did not "know" what Camille was capable of doing next. The "moment" was clearly taking a toll on me. ${ }^{8}$

Two weeks passed and the semester came to a close. Nothing more became of the grievance threat, and I never saw or heard anything about Camille again. It seems I would have simply forgotten about her and the incident that occurred in that course. After all, I am in the autumn of an academic career that began during a much tougher time for me as a multicultural teacher educator. I started during the Reagan administration when explicit resistance to my work came from various quarters and was wildly rampant. Still, never had a student disrespected me publicly. This is to say that the "moment" with Camille reverberated in a way that was unmatched by any previous encounter.

\section{My Connection with the President}

The incident between Camille and me occurred more than two years after the one involving President Obama and Representative Wilson and, on all but a few levels, the contrasts between the two could not be starker. Whereas the former occurred near the end of a brief learning activity used to introduce a semester-long study of cultural diversity in U.S. schools, the latter came near the start of the formal introduction of a national policy initiative for health care reform. The President's ordeal was broadcast live from the cavernous auditorium of the U.S. House of Representatives; mine took place in the cramped confines of a university classroom. Nevertheless, the two incidents provoked an almost identical disquiet in me. Both involved gross breaches of decorum resulting in offensive outbursts. Each involved a verbal assault on a Black person by a White person and, as the targets of White aggression, the Blacks were stunned into momentary silence. In both incidents the Whites held positions of lower status and arguably lesser power than the Blacks, yet the Whites asserted in a manner that reflected clear disregard and disrespect for the legitimacy of the differentials. As I tried to encapsulate why I had experienced a similar visceral reaction to these otherwise grandly dissimilar incidents, I found myself drawn to Wilson's now infamous invective. I called the two incidents examples of a "you lie 
moment." By adding the word "moment," I changed Wilson's invective from a verb phrase to a pre-modifier noun phrase intended to serve as an evocative trope.

A "you lie moment" (or "moment" for short) represents an ostensibly isolated incident along with the critical reflection prompted by it. The critical reflection occurs in relation to the broader context in which the moment-triggering incident has taken place. Moreover, the significance of the reflection comes from its ability to proffer explanation for why a moment-triggering incident of some type was bound to occur. Recalling President Obama's "moment-triggering incident," I remembered how months prior to its occurrence the mere reality of a Black president seemed to have provoked intractable political gridlock and polarization. Oddly enough throughout his first term, like the too desperate partner in a painfully tenuous liaison, President Obama was awash in what Toobin (2012) adroitly termed "unrequited bipartisanship" (p. 116).

I believe each moment-triggering event has an antecedent (if not a series of them) that is entangled in a network of events and occurrences. Sometimes (as in the case of President Obama) identifying antecedents to a momenttriggering event is simple. Wilson's public rebuke had been generously prefaced by a collection of insults and abuses directed at President Obama by other politicians and a string of influential conservative media commentators (Toobin, 2012). Conversely, in other cases (such as my own) the network of occurrences may be opaque and therefore create a challenge to identify definitively those that represent direct antecedents to the moment-triggering event. Still, the incident with Camille was clearly moment triggering for me because it prompted me to examine the broader context in which my work had been (and currently is) situated. As a direct result of the "moment," I came to see persistent resistance to diversity goals and critical multicultural education in my own academic department.

\section{Lessons Learned in "A Moment"}

The incident with Camille represented a jolting wake-up to what had changed about my work over the years, but in its aftermath I was drawn to an exploration of what had persisted. I became intrigued by a situation that had been going on almost imperceptibly within my department, so I engaged in a connect-the-dots type activity involving incidents that had occurred before and subsequent to my moment-triggering event with Camille. Through this activity I was struck by the Janus-like character of the response to a departmental diversity goal requiring all $\mathrm{PhD}$ students to complete the Advanced Seminar in Multicultural Education (ASME), another course that I teach. On the one hand, the departmental faculty had unanimously endorsed the requirement; on the other hand, numerous members were engaging in academic advising practices that nullified it. Enrollment in the ASME requires students to have completed a prerequisite course; thus in reality two multicultural courses (rather than one) are 
required. I discovered a dense network of antecedents that I believe had created, at least in part, the fertile ground in which Camille's aggression toward me had germinated. Over a period of months I noticed that I had received multiple requests from $\mathrm{PhD}$ students to enroll in the ASME sans completion of its prerequisite. ${ }^{9}$ The "moment" had prompted me to follow the trail of those students whom I had denied enrollment to the ASME. In so doing I learned that many were not being advised to take the ASME prerequisite. ${ }^{10}$ Further, I discovered that a number of students (not permitted to enroll in the ASME sans prerequisite) were being allowed to complete their degree programs without having taken any multicultural education course. This successful albeit disturbing circumvention of multicultural education was occurring because students were being allowed to reach the final semester in their programs in which ostensibly the sole remaining degree requirement was the oral defense of the dissertation. To enforce the ASME requirement in such cases would have meant those students would need to delay graduation by an entire academic year in order to complete the prerequisite course in multicultural education followed by the ASME. ${ }^{11}$ Thus, a lesson learned in a "moment" surrounded my becoming re-sensitized to a layer of resistance that had long existed in the broader context of my work as a multicultural teacher educator. In recent years, however, it had been cloaked in a façade that masqueraded as a form of empowered school culture (Banks, 2004). The diversity phrasing ${ }^{12}$ that permeated formal policies (e.g., mission statement, conceptual framework) created the illusion of a respect for social justice and gave rise to the ASME requirement, but was brought up short by the reality of insidious push back.

\section{The Plasticity of Persistent Resistance}

Ultimately, the race-tinged feature of my moment triggering-event with Camille coupled with what strikes me as the anti-multicultural undertones ${ }^{13}$ of advising practices among some of my own departmental colleagues prompted me to try to discern correspondences. In particular, I became interested in examining the duplicitous nature of the resistance I had uncovered in relation to the ASME requirement and the malleability of race itself. I recalled a definition of race proffered by critical race theorist Haney-López (2000) who described it as "neither an essence nor an illusion, but rather an ongoing, contradictory, selfreinforcing, plastic process subject to the macro forces of social and political struggle and the micro effects of daily decision" (p. 165). For me this description of race was at once intriguing and imprecise due to the concept of plastic. Then, by way of a casual conversation, my "moment" led me unexpectedly to the world of physics and engineering science. In so doing, I found an unlikely pathway to better understand a disturbing correspondence between the nature of race and the persistent resistance to critical multicultural education that I now recognized had been taking place in my department.

Specifically, I learned that to speak of something as plastic is to make 
reference to its capability more so than its characteristics (Havner, 1992). For example, in order to discern the plastic capability of materials such as metals or silicates (e.g., glass, concrete, and bricks) they must be subjected to stress conditions or what engineering scientists refer to as loadings. Silicates will fracture or disintegrate outright under relatively low levels of stress whereas metals (e.g., steel, aluminum, and copper) can undergo higher stress levels and endure changes in their form without fracturing. The latter phenomenon is known as plasticity. Materials with higher capability for plasticity can take on myriad deformations (shapes) quite dissimilar to their original form, and they can withstand these deformations without fracturing. Most importantly, materials with a high capability for plastic deformation maintain their atomic structure. This means the core or the pre-stress/pre-deformation essence of the material remains intact irrespective of whatever new shape it may assume. ${ }^{14}$

I believe that like race, resistance to critical multicultural education has a very high capability for plasticity. Through my interactions with other multicultural teacher educators, I have come to believe that irrespective of instructional strategy, course mode, learning resources, or even the race of the instructor, critical multicultural education will be met with resistance in some form. To fully appreciate the degree of plastic capability of the resistance, however, one must become cognizant of and attuned to its myriad manifestations. Reflecting on my role as collegial confidant to other multicultural teacher educators over the years, I find that we are often more aware of (and feel directly diminished by) what might be termed the pre-stressed and pre-deformed states of resistance that occur within the context of our classrooms. This type of run-of-the-mill push-back manifests as, say, students disengaging in class, expressing disinterest in course content, or submitting ad hominem evaluations of instructors at the close of a semester. To be sure, resistance in this form is troublesome, and it can take its toll. Over the years, young colleagues have inquired about whether it gets better. This is to say, does the frequency of resistance in its coarser states lessen over time? The truth is, in my experience I have found that it does-my momenttriggering event with Camille notwithstanding. Therefore, I know that to steady the analytic lens exclusively on the pre-deformed states of resistance is bound to fall short in illuminating the more pernicious sources of persistent resistance to multicultural education. Instead, through critique of the would-be innocuous activities that occur beyond our classrooms yet are firmly entrenched in the institutional context of teacher education (Marshall, 2002c), one is more likely to uncover the real staying power and plastic capability of resistance to multicultural education.

My "moment" inspired me to follow the tracks in one department of teacher education, and I was led to evidence of faculty culpability in undermining diversity goals, which indirectly (and perhaps directly) served to condone students' active resistance of multicultural education. I am humbled by what amounts to my renewed appreciation for the plastic capability of the resistance I have struggled against virtually my entire academic career. Having successfully risen through the academic ranks, it seems I had become complacent until Camille. The 
"moment" in its full complexity drew me into an analysis and critique of the contours of the "new resistance." Gone is the erstwhile marginal status of diversity that I had encountered throughout the Reagan and Bush years. It has been replaced with a pseudo post-racial (Marshall, 2009) Obama era "social justice" mantra. My "moment" helped me see that the form has changed but the essence of the material is still the same. In the months since I uncovered this situation, I have engaged in activities to expose it. The work has not been without its challenges, and because I have become sensitized to the plastic capability of the resistance itself I am ever mindful that in time it will manifest in yet a different form.

Many of us who don the mantle of critical multiculturalism in teacher education lament myriad diverse encounters with resistance; its vagaries are tiring and potentially demoralizing. We seek respite through various means, probably most commonly relying on the simple expedient of talking with trusted colleagues who provide sympathetic ears and fortifying words. I have been a teacher educator long enough to experience resistance directly and to serve as collegial confidant to many others so targeted. Indeed, the impetus to write about it this time arose, in part, when I recognized I was occupying both spaces almost simultaneously. Shortly after the incident with Camille, a young colleague shared with me that she had just learned undergraduate students had complained to the Department Head about her multicultural education course. Upset over the ordeal she asked, "How do you handle something like this?" I said something to the effect of "one moment at a time."

\section{Notes}

1. All student names are pseudonyms.

2. The previous week Camille abruptly interrupted me in the middle of my short lecture. I paused, yielded the floor to her, and afterwards finished my lecture. Then at the start of the week in which the "moment" occurred, she initiated an exchange of emails over not having earned maximum points for an assignment even though she had not included several of its required sections. Camille noted, "If you truly want each question discussed in detail, will you be flexible in the length of the report?" I replied that I really do want students to complete assignments as indicated and those who do not will receive grades that reflect their inattention to the directions. Following up, Camille requested to re-do and re-submit her assignment to be re-graded, adding that by doing so she would "truly learn how to write this type of research." I replied that she would not be allowed to re-submit the assignment but that I would be most willing to meet with her to provide tips for how to approach future assignments. Camille did not reply nor did she accept my offer to meet. There was no additional communication between us until the night of the "moment." 
3. Even though at that point the class had met just four times, as a group they exhibited a high degree of camaraderie and ease in their interactions. They ranged in age from mid 20s to late 50s. There were 11 White women (two of whom were my age contemporaries), two female Chinese nationals, two Black females (one of whom was absent the night of the incident), and two White males. The ethnoracial profile of the course was roughly equivalent to that at the university. In hindsight, I suppose I posed the question thinking someone other than I (perhaps one of the mature White women as both had been very talkative in the course up to that point) would say something to soothe Camille.

4. Each time l've taught this course, early in the semester I usually pre-assign students to work together in groups (changing the assignments for each activity) in order to facilitate more diverse groupings and to help students get to know each other.

5. I later learned Camille had already contacted her adviser (a departmental colleague) to drop the course and, as a substitute, she was offered an independent study experience.

6. Nearly eight months later, LaDonna came to my office and after we addressed the primary reason for her visit, she decided to stay to chat and eventually she brought up the "moment." I was surprised because of the amount of time that had lapsed since its occurrence, but I was quite curious to learn what she remembered about that evening and her impressions of how I reacted. I was also curious to hear her explanation for why she invited Camille to join in during the second small group activity. I asked LaDonna to share her honest opinion. She recalled fine details about the evening including my initial request for students to form the large group. Also, she recalled Camille's initial response to me. LaDonna indicated that she had been incredulous over the way Camille had spoken to me and noted that I had responded calmly. She shared that immediately after the class session she had telephoned her mother (who is an elementary school principal) to detail what had occurred in that class session. Remembering how she opened the conversation with her mother that evening, LaDonna recalled saying, "Mom, you're not going to believe what happened in class tonight." When I asked LaDonna why she had taken it upon herself to invite Camille to join the second small group, LaDonna replied that she teaches middle-school students and had perceived Camille to be acting like the teenagers she deals with every day. Although I did not share this with LaDonna, her overture that evening had troubled me greatly. I had shared with a few Black collegial confidants how LaDonna had responded to Camille. Their unanimous response had been that LaDonna's actions exemplified a different longstanding Black female stereotype-the mammy. Two colleagues speculated that to Camille that stereotypical image of a Black woman was likely far more acceptable and comforting than the one I apparently had projected. 
7. The ADSE cautioned that due to confidentiality only general information could be shared about the meeting with Camille.

8. During my meeting with the Department Head I expressed concern for my physical safety and was advised to contact the University Risk Assessment Case Manager whose job is to ascertain the degree of threat and imminent danger a student (or other individual) may pose to persons on the campus. After meeting with the ADSE, I followed up with a telephone call to the Case Manager who, as a precaution, advised me to stop holding my late afternoon/evening office hours. For years I had held evening office hours to accommodate students whose jobs as classroom teachers made it impossible for them to arrive on campus during the day or early afternoon. Eventually, it was determined that I was not facing imminent danger, but I was advised to contact the office again if I saw Camille and felt threatened by her presence.

9. The course in which the moment triggering event took place serves as one option (from a selection of two) that can serve as the prerequisite course for the ASME. I have noticed (and was recently told by a White colleague) that students avoid taking that course although over the years many students have informed me it is one of the best courses they have completed in their programs.

10. One PhD student who had enrolled in the prerequisite course a year or so prior to "the moment" and subsequently completed the ASME a year after "the moment" had occurred informed me that she had not been advised to take either course. Moreover, she indicated that she knew of several other PhD students who were actively avoiding taking both courses and had not been advised to do so.

11. In some cases PhD students had completed the prerequisite but did not complete the ASME requirement. Two PhD students who were enrolled in the course where the "moment" had taken place did not subsequently enroll in the ASME, yet both graduated.

12. Elsewhere (Marshall, 2002b) I explain that this involves the insertion of catchphrases in formal policy statements without corresponding social justiceoriented actions by the members of a given organization. Thus, catchphrases are exposed as superficial wordplay.

13. A troubling discovery is that consistently it has been the advisees of some of my White colleagues, not my colleagues of color, who have completed degree programs sans any coursework in multicultural education. I hasten to add that issues of personality between some of my White colleagues and me could be operating here; however, that would still leave unanswered the question of why students are not advised to take other multicultural education courses not taught by me.

14. Many thanks to my colleague and friend K. S. Havner, Professor Emeritus of Civil Engineering and Materials Science and Engineering, for helping me 
understand this phenomenon by way of a mini-lesson on the deformation of crystalline solids.

\section{References}

Banks, J. A. (2004). Multicultural education: Historical development, dimensions, and practice. In J. A. Banks \& C. A. McGee Banks (Eds.), Handbook of research on multicultural education (2 ${ }^{\text {nd }}$ ed., pp. 3-49). Washington, D.C.: American Educational Research Association.

Boylorn, R. M., \& Orbe, M. P. (Eds.). (2014). Critical autoethnography: Intersecting cultural identities in everyday life. Walnut Creek, CA: Left Coast Press.

Chinn, P. (Producer). (2004). Culturally responsive teaching. [Video]. National Association for Multicultural Education, Washington, DC.

Collins, P. H. (2009). Black feminist thought: Knowledge consiousness, and the politics of empowerment. New York, NY: Routledge.

Donovan, R. A. (2011). Tough or tender: (Dis)similarities in white college students' perceptions of black and white women. Psychology of Women Quarterly, 35(3), 458-468.

Ellis, C., \& Bochner, A. P. (2000). Autoethnography, personal narrative, reflexivity: Researcher as subject. In N. K. Denzin \& Y. S. Lincoln (Eds.), Handbook of qualitative research $\left(2^{\text {nd }}\right.$ ed.) (pp. 733-768). Thousand Oaks, CA: Sage Publications, Inc.

Hahn, S. (2012, November 11). Political racism in the age of Obama. The New York Times, p. SR6.

Haney-López, I. F. (2000). The social construction of race. In R. Delgado \& J. Stefancic (Eds.), Critical race theory: The cutting edge $\left(2^{\text {nd }}\right.$ ed, pp. 163175). Philadelphia, PA: Temple University Press.

Hartman, C. (2003). The race/poverty intersection: Will we ever achieve liberty and justice for all? Practicing Social Justice, 22(2/3), 55-62.

Havner, K. S. (1992). Finite plastic deformation of crystalline solids. Cambridge, UK: Cambridge University Press.

Jenks, C., Lee, J. O., \& Kanpol, B. (2001). Approaches to multicultural education in preservice teacher education: Philosophical frameworks and models for teaching, The Urban Review, 33(2), 87-105.

Kaplan, A. (1993). French lessons: A memoir. Chicago, IL: University of Chicago Press.

Ladson-Billings, G. (1998). Just what is critical race theory and what's it doing in a nice field like education? Qualitative Studies in Education, 11(1), 7-24. 
Marshall, P. L. (2009). Multicultural education in a post-race political age: Our movement at risk? Multicultural Perspectives, 11(4), 188-193.

Marshall, P. L. (2002a). Cultural diversity in our schools. Belmont, CA: Cengage.

Marshall, P. L. (2002b). The persistent deracialization of the agenda for democratic citizenship education: Twenty years of rhetoric and unreality in social studies position statements. In G. Ladson-Billings (Ed.), Critical race theory perspectives on social studies: The profession, policies, and curriculum (pp. 71-97). Greenwich, CT: Information Age Publishing.

Marshall, P. L. (2002c, February). The demystification of that dispositions thing: Drawing upon lessons from racial identity scholarship to name and dismantle obstructionist forces in SCEDs. In P. L. Marshall (Chair), Playing in the dark: What some of us still don't get about preparing teacher candidates for cultural diversity in an age of accountability. Symposium at the Annual Meeting of the American Association of Colleges for Teacher Education, New York, NY.

Marshall, P. L. (1996). Multicultural teaching concerns: New dimensions in the area of teacher concerns research? The Journal of Educational Research, 89(6), 371-379.

Nieto, S. (1999). The light in their eyes: Creating multicultural learning communities. New York, NY: Teachers College Press.

Noguera, P. A. (2001). Racial politics and the elusive quest for excellence and equity in education. Education and Urban Society, 34(1), 18-41.

Orfield, G., \& Lee, C. (2006). Racial transformation and the changing nature of segregation. Cambridge, MA: The Civil Rights Project at Harvard University.

Sleeter, C. E. (2001). Preparing teachers for culturally diverse schools: Research and the overwhelming presence of whiteness. Journal of Teacher Education, 52(2), 94-106.

Sleeter, C. E., \& Grant, C. A. (2009). Making choices for multicultural education. Five approaches to race class, \& gender $\left(6^{\text {th }}\right.$ ed.). Hoboken, $\mathrm{NJ}$ : John Wiley \& Sons.

Stringer, D. M., \& Cassiday, P. A. (2003). 52 Activities for exploring values differences. Yarmouth, ME: Intercultural Press.

Tillman, L. (2011). Sometimes I've felt like a motherless child: Being Black and female in the academy. In S. Jackson \& R. G. Johnson, III. (Eds.), The Black professorate: Negotiating a habitable space in the academy (pp. 91107). New York, NY: Peter Lang Publishers.

Toobin, J. (2012). The oath: The Obama white house and the supreme court. New York, NY: Doubleday/Random House. 
Zumwalt, K., \& Craig, E. (2008). Who is teaching?: Does it matter? In M. Cochran-Smith, S. Feiman-Nemser, D. J. McIntyre, \& K. E. Demers (Eds.), Handbook of research on teacher education: Enduring questions in changing contexts ( ${ }^{\text {rd }}$ ed., pp. 134-156). New York, NY: Routledge.

\section{Author Contact}

Patricia L. Marshall, plmarsha@ncsu.edu

North Carolina State University, Department of Teacher Education and Learning Sciences, Raleigh, NC 27695, USA 